\title{
電算機による横断シンチグラフィー
}

\author{
新潟大学医学部放射線医学教室（指導 北畠 隆教授） \\ 柏森宽*
}

（論文受付，昭和51年 9 月24日）

(Code No. 341, 350)

\section{TRANSVERSE SECTION SCINTIGRAPHY BY MEANS OF COMPUTER CALCULATION.}

(Article received; Sep. 24, 1976)

\author{
by RYO KAYAMORI \\ Department of Radiology, Niigata Uni- \\ versity school of Medicine, Niigata (Di- \\ rector: Takashi Kitabatake)
}

\begin{abstract}
Summary
A method of taking transverse section scintigraphy using a minicomputer and Anger-type camera is described. A rotating table for a patient is so set that the rotation center should be placed within perpendicular line of the center of the detector facing sideways. Scintigrams taken from at 4 directions $\left(0^{\circ}, 90^{\circ}, 180^{\circ}\right.$ and $270^{\circ}$ ) are recorded on the magnetic tape. Radioisotope distribution in an X-Y-Z-coordinate system is subdivided into $40 \times 40 \times 40$ matrix of equal size. The counts divided are given to each elements. Density values could be represented from 10 to 100 percent in $40 \times 40$ matrix.

In a phantom study using the Alderson mock liver, $3 \mathrm{~cm}$-and $4 \mathrm{~cm}$-sized cold areas were well demonstrated on the transverse section image. Several fundamental experiments were performed using a point source in polyvinyle tube, and the resolving power was obtained to be $1.5 \mathrm{~cm}$. Some clinical trials of the normal brain and liver were also demonstrated.
\end{abstract}

1. 目 的

回転偏向 CRT によると直接横断面シンチグラフィ一 を撮影することができるが，ての方法において横断厚を 薄くすれば，スプリッタ中のカウントが減少し横断面形 成に長時間を要する，又スプリッタ中の幅を広くすれば 横断面に墘けを生じ解像力が低下するという矛盾があ る. そこで CRT 方式を断念し，電算機を使用するデジ タル横断シンチグラフィーについて検討したので報告す * 現新潟大学医療技術短大放射線技術学科
る.

\section{2. 方法および結果}

本法での横断シンチグラフィを得る手順を Fig. 1 亿示 す.

被写体を回転台に乗せる. 検出器を回転台の回転軸に 直角に向け，被写体（目的蔵器）の4 方向 $(0,90,180$ $\left.270^{\circ}\right)$ からのシンチグラムを電算機 (PDP-12C，8K語・ 記憶容量) を通して磁気テープに記録させる４４方向全 部のデータを収録した後、横断面を形成したい部位を決 

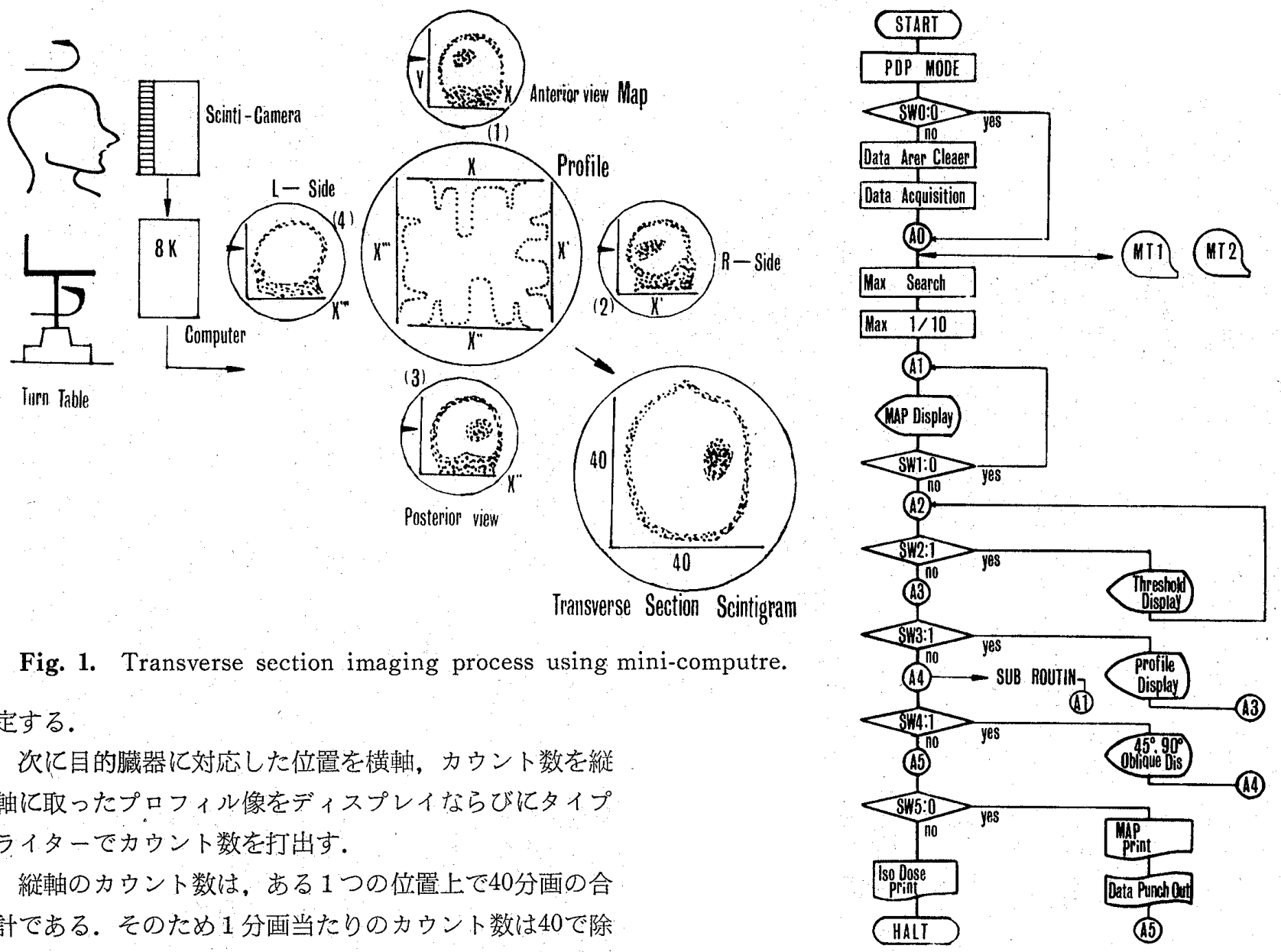

Fig. 1. Transverse section imaging process using mini-computre.

定する。

次に目的臓器に対応した位置を横軸，カウント数を縦 軸に取ったプロフィル像をディスプレイならびにタイプ ライターでカウント数を打出す.

縦軸のカウント数は，ある1つの位置上で40分画の合 計である.そのため 1 分画当たりのカウント数は40で除 して，一律に平均カウントで重みづけをする。横断面を 形成するには，1分画当たり4方向からのカウントを加 算し、オフ・ラインで数的処理を加えて，同様に1600分 画 $(40 \times 40)$ について行なう.

デジタル合成によって得た横断面を CRT上に表示す る. そのメィン・フローチャートが Fig. 2 である。

\section{1 基礎実験}

Alderson 製肝ファントムに ${ }^{99 \mathrm{~m}} \mathrm{TcO}_{4}^{-}-1 \mathrm{mCi}$ を封入し， 径 $3 \mathrm{~cm}$ および $4 \mathrm{~cm}$ のプラスチック球を入れて、次損 像が得られるかを試みた。

4 方向の MAP 像およびそのプロフィル像が Fig. 3(a) であり．Fig. 3(b) は MAP 像（知印）で同一ライン上 における合成後のデジタル横断シンチグラムである.

得られた横断面像を, カット・オフ・レベルの下限值 を変え $100 \%$ (最高值) まで表示した。一限值 $40 \%$ 以上 で明瞭な欠損像が得られている。

次に径 $0.4 \mathrm{~cm}$, 長さ $46 \mathrm{~cm}$ のビニール製チューブに ${ }^{99 m} \mathrm{TcO}_{4}$-を満たし, 図 (Fig. 4(a)) のでとく、2本のビ ールチューブの間隔を $1.5 \mathrm{~cm}$ として. 簡単な解像力テ ストを行なった。

そのデジタル横断シンチグラムが Fig. 4(b) であ
Fig. 2. Flowchart of main program in transverse section scintigraphy.

る。

シンチ・カメラで撮影したシンチグラムでは，2本の ビニールチューブの $1.5 \mathrm{~cm}$ の間隔は明睹に判別できる が、ディジタル横断イメージでは下限值が10\%あるいは 30\%以上の場合に，かろうじて判読できる程度である。

\section{2 臨，床例}

正常人の脳と肝臓について。横断イメージを得た，脳 は ${ }^{99 \mathrm{~m}} \mathrm{TcO}_{4}-7.5 \mathrm{mCi}$ ，静脈より投与し，1 時間後のシン チグラムである。

肝蔵は ${ }^{99 \mathrm{~m}} \mathrm{Tc}$-Sn-Colloid $1.5 \mathrm{mCi}$ 静注後の30分におけ るシンチグラムである，各々 MAP 像（正面，右側面） において横断部位の決定（矢印）を行ない，そのデジタ ル横断面像が Fig. 5 である。得られた横断面では，脳， 肝蔵とも輪郭がなめらかでなく，特に脳のデジタル横断 イメージは箱のような形が得られた。

\section{3. 考按}

回転偏向 CRT 方式は掃引線が CRT 螢光面上, $360^{\circ}$ 


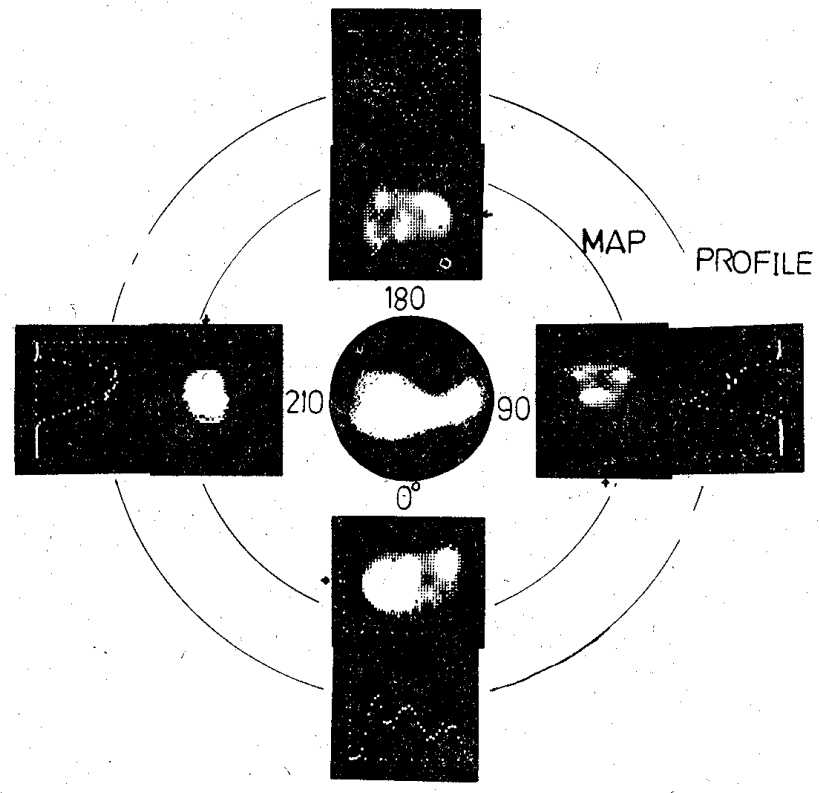

(a)

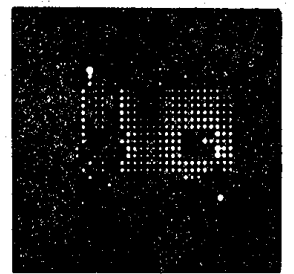

$40-100$

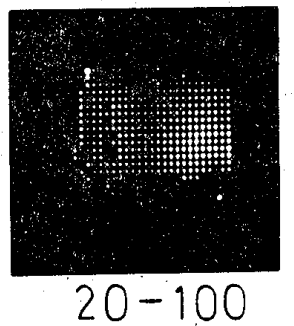

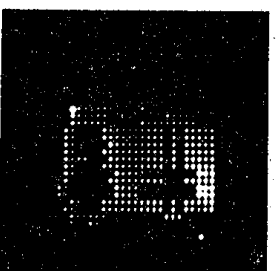

$50-100$

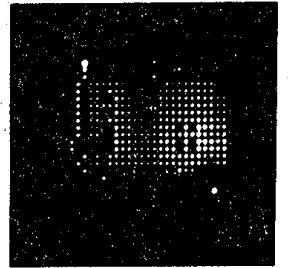

$30-100$

(b)

Fig. 3. (a ) Four MAP projection of the Alderson liver mock phantom.

(b) Reconstruction of transverse section image. Numericals indicate the cut-off level.

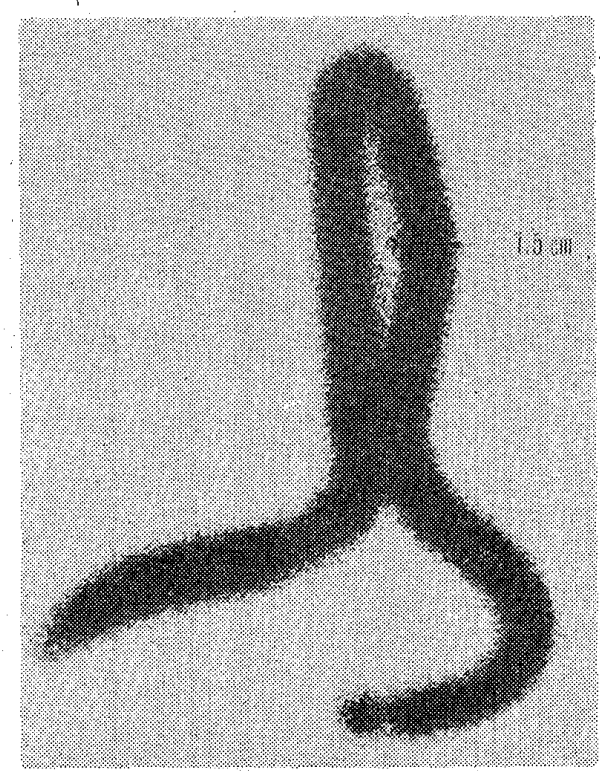

(a)

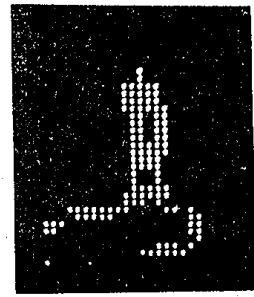

$10-$

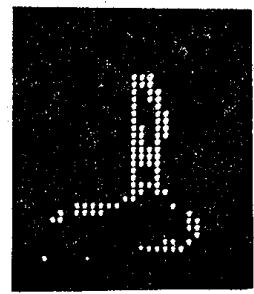

$50-$

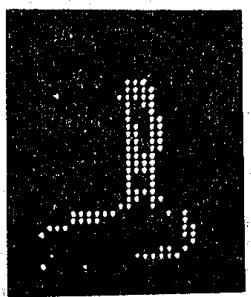

$30-$

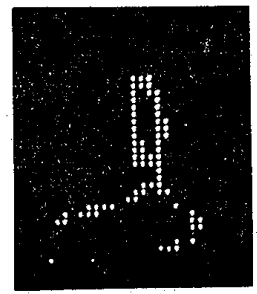

$70-$

(b)

Fig. 4. (a) Original single scintiphotography of a polyvinyle tube $(\mathrm{W}-0.4 \mathrm{~cm}, \mathrm{~L}-46.0 \mathrm{~cm})$ including radioactive technetium.

(b) Transverse section image of (a).

に亘って回転していく間に，長い時間残光として残るこ とは横断シンチグラムの解像力を悪くする．又横断厚の 決定ではスプりッタ内に入る RI からの放射線のみで設 定でき，理論上 $1 \mathrm{~cm}$ でも可能であるが， $\mathrm{CRT}$ 螢 光面 上は表示される掃引線の密度によって，得られた横断シ チグラムの濃度に差ができる。乙のため $2 \mathrm{~cm}$ 厚が最適 であった。
とれらの解決方法の一法として電算機を用い，患者又 は被写体の周囲各方向で撮影した成分を数的に合成して 横断シンチグラムを得る方法が Muechllehner2), 橿尾 ${ }^{3)}$ らにより報告されている：前者の報告では，シンチカメ ラの検出部を被写体回転中心軸に直角になるように向け， 被写体周四 8 方向 (45間隔) でシンチグラムを撮影す る. 各方向のシンチグラム・データを電算機に記憶させ 


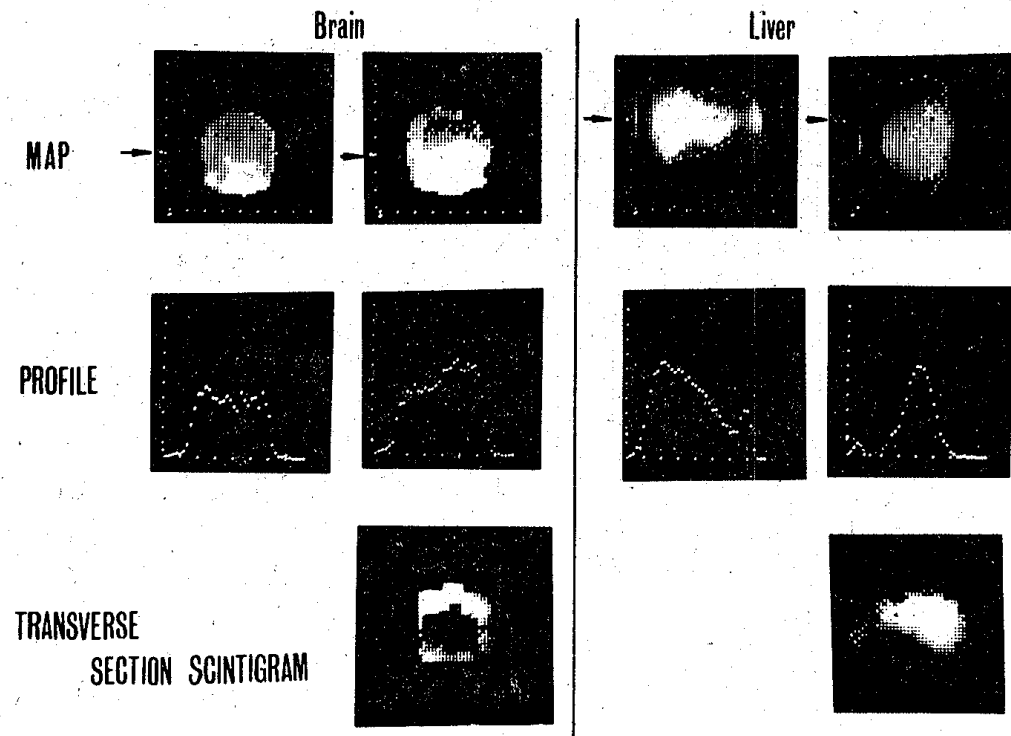

Fig. 5. Clninacl trials of the normal brain and liver.

て測定する．いずれかの検出器がガンマ線 を検出するごとに、その検出器の位置と方 向に相当する輝線を CRT 上に表示し，各 方向为らの輝線をポラロイドフイルム上に 蓄積させるものである。

Kuhl らの方式では，4個の 検出器を方 问ごとに走查する必要があり，測定時間が 非常に長い. 又, ガンマカメラでの高エネ ルギーのケ線に対しての感度の增加及び平 行多孔コリメータを用いるため一つの横 断面に対する検出効率の问上の為, “橿尾 ${ }^{3}$. らは，Kuhl ら亡原理的には似ているが， 多結晶の検出器を 4 個, 患者们中心点を置 き，その回転円周上に配置した装置を開発 した。検出器が 4 個同時に们周上，更には 横断像の画質の向上のために各検出器を独

ておいて，その後に1600 $(40 \times 40)$ 分画を数的に処理し， 一面の横断像として CRT 上に表示する.

計算好理の手順を $16(4 \times 4)$ の分画についてわかり易く 展開している。

第 1 ステップとして， 1 方向 $\left(0^{\circ}\right)$ 撮影で 4 つの位置 上での各カウント数は 4 分画あたりの合計であるので， 1 分画あたり 4 で除し一律に平均カウント数を与える. 次に0方向撮影さ同じように45，90，135方向について 6計算圭行なう。1 分画で各 4 方向からの平均カウント 数を加算する. 一面16分画のカウント数の多い分画を 1 として, 計算後の合成面を作る。第 2 ステップ，むる一 つの角度方向から撮影したときの分画数の合計，つまり $0^{\circ}$ 方向撮影は全部 4 分画の合計であるが， $45^{\circ}$ 方向撮影 では，端加 1，2，3，4，3，2，1分画となる。

1 分画当たりに与えられた平均カウント数で同一カウ 卜值をみつけ出し，最初被写体周囲の各方向で撮影した シンチグラム・データから，その同一カウント值を差引 く. 次に差引かれたシンチグラム・データから、ステッ プ1の方法をくりかえし，計算後の合成面を作る。周囲 4 方向撮影データが消去されるまで計算処理を続ける。 計算合成面をカウント数に対応した輝度て CRT 上に表 示する.

$\mathrm{Kuhl}^{4)}$ らは大がかりな装置を用いて，4個のシンチレ ーション检出器を患者頭部の周囲に配置し，これらをそ れぞれ走査することにより，頭部のある断面に沿った 4 方向のプロフィル像（一次元）を求め，一回の走查が終 ると各検出器を元の位置にもどしてから、4つの検出器 を頭部を中心にして少し回転させる，それを再び走查さ
自に動かすととができる。乙の装置を使用して得られた 各位置信号と共に横断イメージとして CRT 上に表示し。 電算機に入力するためのデジタル・データが得られる. $\mathrm{CRT}$ 上には種々の方向からの輝線を表示するため，二 般の静電偏向形オシロスコープを使用し，検出器の角度 を検出して静電的に行なっている，検出装置に違いはあ るが，著者らが以前）隹試みた，ガンマ・カメラを使用 し、検出部を横向きに設定し，その前で被写体をゆっく り回転させる。ガンマ・カメラは電気的にスリット状の 部分の信号を取り出し, 被写体 $360^{\circ}$ 回転し, 煇線をCRT 上に表示ざせるとによって，横断イメージをポラロイ ドフィルム上に蓄積される方法と同じである。

このように横断シンチグラフィーの特徴は，問題とす る面以外に存在するRI の像が重複しないことである。 しかし点が直線の合成として作られるため，画像は通常 のシンチグラムとはかなり違った画質を示すととが欠点 である。

その点 Muehllehner らと著者らは，電算機を用い。 被写体の臓器内に分布する RI の樑さの情報をガンっ・ カメラを道して電算機に入力し，被写体周国各方向のシ ンチグラム・データから計算処理を行ない通常のシンチ グラムの画質のように CRT上に表示した点に特色があ る. 又橿尾らと協同研究者である Tanaka, Iinuma ${ }^{6)}$.ら は，多結晶の検出器を用いて，検出器の各位置信号と共 にシシチグラム情報を電算機に入力し，各位置のプロフ ィル像から計算処理を行なっている。

Muechllehner らでは被写体周囲の撮影が 8 方向であ るのに比し，著者らは 4 方向である。しかし 8 方向， 4 
方向撮影であ実際はその半分の 4 方向， 2 方向での撮影 と同じ理屈と考元られる.

横断シンチグラムは，被写体の周囲の成分を含んでい るあのである．とすれば 4 方向や 2 方向程度の撮影では 横断イメージとは言えない疑問が生じる.

ての点を考慮して， $360^{\circ}$ 全般にわたるシンチグラム撮 影を行ない，電算機による計算処理を検討中である.

又 1 方向撮影で得た MAP 像を $40 \times 40$ 亿分画して合成 を行なったが, 欠損像として認識するには分画数が少な すぎる。

しかし, 現有の検出器一被写体回転中心までの距離 25 $\mathrm{cm}$ では, 距離が離れるととによって生じるコりメーシ ョンの問題7)から考えれば 1 方向撮影の MAP 像形成は $4096(64 \times 64)$ 分画が限度であろうと思われる.

\section{4. 結 論}

小型電算機と Anger 型シンチ・カメラを用いた横断 シンチグラフィを得る方法を述べた.

患者を載せる回転台の回転中心軸に対して直角になる ように検出器を設定した。

被写体周困 4 方向 $\left(0,90,180,270^{\circ}\right)$ 撮影のシンチ グラムを電算機を介して磁気テープ上に記録する．Radioisotope の分布をX-Y-Z の坐標系に分け，各 $40 \times 40$ $\times 40$ で分ける.

$\mathrm{X}$ 座標軸上に执いて，垂直面を $\mathrm{Y}$ ，平行多孔コリメー タが視行している面をZとし，40×40亿分ける．X軸上 の任意の点上に拉ける值は $Z$ 面での40分画の合計值であ る. そのため 1 分画中のカウント成分は 40 で割り，各分 画中に与える。乙林值はプロフィル像からのデータ に基づき，各列に沿って400分画上でたし合わされる。 $40 \times 40$ 分画面での再合成後で計算值と対応した濃度值で
表わしたものが Fig. 3(b) である．濃度值は $40 \times 40$ 分画 面で10 100\% までの値を表わすととができる.

$3,4 \mathrm{~cm}$ の欠損球とアルダーソン製肝ファントムの中 に入れたファントム実験では，明瞭な欠損像を示現でき た。

又塩化ビニールチューブの中に RIを入れた陽性像の 解像力テストでは $1.5 \mathrm{~cm}$ であった.

正常の脳之肝臟の横断シンチグラム像を試みた。

（本論文の一部は、第26回日医放・物理部会1973.10. 17 (青森)，第14回日本核医学会総会1974.7.13 (東京) に扔いて講演した。)

\section{文 献}

1)北畠 隆，他：横断シンチグラフィーの開発. 核医 学, 8,423-429, 1971.

2) Muechllehner. G., et al. : Section imaging by computer calculation. J. Nucl. Med., 12, 76-84, 1971.

3). 楅尾英次, 他: 横断シンチグラフ装置. 東芝レビュ $-, 2,130 \sim 134,1974$.

4) David. E. Kuhl, et. al.: Cylindrical and Section Radioisotope Scanning of the Liver and Brain. Radiology, 83: 926-936, 1964.

5) 柏森 亮, 他: 改良 CRT による横断シンチグラフ ィ一, 核医学, 12, 291-294, 1975.

6) E. Tanaka, et al.: Multicrystal Section Imaging Device and its Data Processing. Volume 2 of the Proceeding of the XIII International congress of Radiology. 314-324, Madrid, 1973.

7) 久田欣一, 他: 核医学竛断法としての Scintillation Camera の意義について。臨床放射線，14，1-12， 1969. 